\title{
Helminths of Molothrus bonariensis (Gmelin, 1789) (Passeriformes: Icteridae) from southernmost Brazil
}

\author{
Helmintos of Molothrus bonariensis (Gmelin, 1789) (Passeriformes: Icteridae) do extremo sul do Brasil \\ Fabiana Fedatto Bernardon ${ }^{1 *}$; Tatiele de Aguiar Lopes Soares ${ }^{1}$; Thainá Dutra Vieira ${ }^{1}$; Gertrud Müller ${ }^{1}$ \\ ${ }^{1}$ Laboratório de Parasitologia de Animais Silvestres - LAPASIL, Departamento de Microbiologia e Parasitologia, Instituto de Biologia, \\ Universidade Federal de Pelotas - UFPel, Pelotas, RS, Brasil
}

Received October 15, 2015

Accepted May 11, 2016

\begin{abstract}
Information about helminths of Molothrus bonariensis (Gmelin, 1789) (Passeriformes: Icteridae) are scarce; in this sense the objective of this paper was to contribute to its knowledge. Five hosts of southern Brazil were examined and the helminths Prosthogonimus ovatus, Tanaisia valida (Digenea), Diplotriaena bargusinica and Synhimantus (Dispharynx) nasuta (Nematoda) were identified. The species T. valida, P. ovatus and $S .(D$.) nasuta are for the first time registered for the bird in Brazil. Prosthogonimus ovatus, T. valida, D. bargusinica e S. (D.) nasuta are first recorded in M. bonariensis in the southern Brazilian state Rio Grande do Sul.
\end{abstract}

Keywords: Shiny cowbird, Trematoda, Nematoda, parasites.

\section{Resumo}

Informaçôes sobre helmintos de Molothrus bonariensis (Gmelin, 1789) (Passeriformes: Icteridae) são escassas, nesse sentido, o objetivo do trabalho foi contribuir para esse conhecimento. Foram examinados cinco hospedeiros do extremo sul do Brasil, identificou-se os helmintos Prosthogonimus ovatus, Tanaisia valida (Digenea), Diplotriaena bargusinica e Synhimantus (Dispharynx) nasuta (Nematoda). As espécies T. valida, $P$. ovatus e $S$. (D.) nasuta são pela primeira vez registradas para a ave no Brasil. Prosthogonimus ovatus, T. valida, D. bargusinica e $S$. (D.) nasuta sáo pela primeira vez registradas em M. bonariensis no estado do Rio Grande do Sul.

Palavras-chave: Vira-bosta, Trematoda, Nematoda, parasitos.

Parasites are among the most common organisms in the world (HOBERG \& KUTZ, 2013). They are extremely diversified and play a key role in ecological and evolutionary processes (GOMÉZ \& NICHOLS, 2013). Parasitism is one of the most successful ways of living presented by living organisms (POULIN \& MORAND, 2000).

Birds are commonly parasitized by trematodes, nematodes, cestodes and acanthocephalans, as well as other groups (AMATO \& AMATO, 2010). Taking into account the fact that Brazil presents one of the richest avifaunas in the world, much remains to be explored regarding this subject.

Molothrus bonariensis (Gmelin, 1789) (Passeriformes: Icteridae), known as the shiny cowbird, occurs in South America, islands of Central America, United States and Canada (The IUCN Red List of Threatened Species, 2015). In the state of Rio Grande do Sul, Brazil, they inhabit the entire state, where enormous flocks often gather in cereal crops, especially rice, during and after harvesting (BELTON, 1994). The male is black-feathered with

*Corresponding author: Fabiana Fedatto Bernardon. Universidade Federal de Pelotas - UFPel, CP 354, CEP 96010-900, Pelotas, RS, Brasil.

e-mail: fabifedatto@gmail.com bluish reflexes, and the female is brown. They feed on seeds and insects, and occasionally on fruits, and often can be seen near to cattle, turning over excrement to look for undigested seeds (EFE et al., 2001).

Information regarding the shiny cowbird is mainly focused on the fact that this species lays its eggs in other birds' nests. In Brazil, approximately 60 species belonging to nine families of Passeriformes are affected by the action of the shiny cowbird. This species is entirely dependent on other bird species for its reproduction, because it has not only lost the ability to build its own nests but also the instinct of taking care of its offspring (BLANCO, 1995; SICK, 1997; EFE et al., 2001; MERMOZ \& REBOREDA, 2003; ASTIÉ \& REBOREDA, 2006).

Regarding helminths in $M$. bonariensis in Brazil, there have been isolated reports of Lyperosomum oswaldoi (Travassos, 1919) (Trematoda: Dicrocoeliidae) (TRAVASSOS et al., 1969), Diplotriaena bargusinica Skrjabin, 1917 (Nematoda: Diplotriaenidae) (VICENTE et al., 1983) and Mediorhynchus emberizae (Rudolphi, 1819) (Acanthocephala: Gigantorhynchidae) (PETROCHENKO, 1971). In this context, the present study had the objective of reporting the presence of helminths associated with $M$. bonariensis. 
Five hosts were examined (one male and four females), originating from the municipality of Rio Grande, Rio Grande do Sul, Brazil (320 14'.37.24" S; 52 29'38.71" W) two birds in the summer and three in the winter. They were accidentally sampled in a trap that had been set to catch Chrysomus ruficapillus (Vieillot, 1819) (Passeriformes: Icteridae), in accordance with a license granted by the Instituto Chico Mendes de Conservação da Biodiversidade (ICMBio No. 41095-3) and approval granted by the Comitê de Ética e Experimentação Animal from the Universidade Federal de Pelotas (CEEA/UFPel No. 147), covering the period of 2013-2015.

These specimes of Molothrus bonariensis were euthanasied, individually placed in identified plastic bags, and were transported to the Laboratório de Parasitologia de Animais Silvestres (LAPASIL/UFPel) and frozen until processing. To collect helminths, were necropsied and their organs (mouth, esophagus, proventriculus, gizzard, cecum, small and large intestines, trachea, lungs, heart, liver, gall bladder, pancreas, reproductive system, kidneys, cloaca and air sacs) were separated from each other, opened and rinsed with running water under a sieve of mesh size $150 \mu \mathrm{m}$.

The helminths were fixed in AFA for 24 hours and were stored in accordance with the protocol proposed by Amato \& Amato, 2010. Trematodes were stained with Langeron's carmine and nematodes were clarified with Aman's lactophenol. They were mounted on permanent and semi-permanent slides and photographed through a microscope (Olympus BX 41) with a coupled camera system. Morphological and morphometric identification were performed in accordance with Freitas (1951), Kohn \& Fernandes (1972), Gibson et al. (2002), Bray et al. (2008), Lunaschi et al. (2015) for Digenea, and with Vicente et al. (1983), Zhang et al. (2004) and Anderson et al. (2009), for Nematoda. The parameters calculated were prevalence $(\mathrm{P})$, mean abundance (MA) and mean intensity of infection (MI), in accordance with Bush et al. (1997). The voucher specimens were deposited in the "Coleção de Helmintos do Laboratório de Parasitologia de Animais Silvestres” from Instituto de Biologia, Universidade Federal de Pelotas (CHLAPASIL/UFPel) (No. 612 to 616).

Out of the five hosts Molothrus bonariensis examined four were positive for helminths (only females). Were identified two species of Trematoda Prosthogonimus ovatus (Rudolphi, 1803) (Lühe, 1899) (Prostogonimidae) $(\mathrm{n}=5)$ and Tanaisia valida Freitas, 1951 (Eucotylidae) $(\mathrm{n}=20)$ and two Nematoda Diplotriaena bargusinica Skrjabin, 1917 (Diplotriaenidae) ( $\mathrm{n}=37)(20$ males and 17 females) and Synhimantus (Dispharynx) nasuta (Rudolphi, 1819) Chabaud, 1975 (Acuariidae) $(\mathrm{n}=2)$ (one male and one female), the results for each host and the parasitological indexes are presented in Table 1. Diplotriaena bargusinica was the most prevalent parasite and the one with the highest mean infection intensity, followed by T. valida. The trematode P. ovatus and T. valida co-occurred (one host); D. bargusinica and T. valida (one host) and $D$. bargusinica and $S$. (D.) nasuta (one host). There were not analyzed pathological aspects related to the identified helminths.

The morphological identification of each species was carried out according to the characteristics described by the previously mentioned authors. We present below the relevant aspects of each helminth. P. ovatus (Figure 1) is characterized by having the piriformis body, subterminal oral sucker, muscular pharynx present (Figure 2), simple intestinal cecum, few meandering surpassing the testicles. Acetabulum pre-equatorial, terminal genital pore located next to the oral sucker. Cirrus sac extending from the genital pore to the level of esophageal bifurcation, well-developed testicles, post-acetabular, post-ovarian, equatorial (Figure 3). Ovary pretesticular lobed, Mehlis gland situated below the ovary, uterus occupies half of the body and the excretory portion is terminal.

Tanaisia valida has elongated body, flattened, in tegument with thorns, vitelline glands begging in post-ovarian region to the back of the body (Figure 4), oral sucker subterminal, non visible acetabulum, muscular pharynx (Figure 5), intestinal cecum is positioned dorsally in relation to the gonads fused near to end of the body. Lobate testis with diagonal layout, pre-equatorial, post-ovarian (Figure 6). Lobate ovary, uterus with a large number of eggs, these yellow-brownish color with a smooth shell.

In the anterior region of $D$. bargusinica has a trident well developed (Figure 7), trident with tapered apex (Figure 8), females has a genital opening near to the anterior region (Figure 9), eggs with size range of $0.044 \times 0.029 \mathrm{~mm}$ (Figure 10), females with posterior rounded region (Figure 11), males with uneven spicules with small number of papillae (Figure 12).

Synhimantus (D.) nasuta (Figure 13) has a filiform body, cuticle striated crosswise, small and conic lips, four cords recurrent non anastomosing beginning on surface dorsal and ventral of the oral opening extending to the posterior portion of the muscle esophagus and bifurcated cervical papillae (Figure 14) Females presented well-developed uterine, vulvar opening near the posterior end of the body (Figure 15). Males presented curved caudal end, nine pairs of caudal papillae, four pairs pre-cloacal and five post-cloacal (Figure 16), unequal and dissimilar spicules (Figure 17).

The trematodes Prosthogonimidae (Lühe, 1909) have worldwide distribution. They are parasites of the bursa of Fabricius, oviduct,

Table 1. Helminths and parasitological indexes of Molothrus bonariensis (Passeriformes: Icteridae) are from Rio Grande, Rio Grande do Sul, Brazil.

\begin{tabular}{|c|c|c|c|c|c|}
\hline Helminths & Host & Total helminths/Host & $\mathbf{P}(\%)$ & MA & MI \\
\hline \multicolumn{6}{|l|}{ Trematoda } \\
\hline Prosthogonimus ovatus (Rudolphi, 1803) & $\mathrm{Mb} * 3$ & 5 & 20 & 1 & 5 \\
\hline Tanaisia valida Freitas, 1951 & $\mathrm{Mb}^{*} 3, \mathrm{Mb}^{*} 4$ & $11 ; 9$ & 40 & 4 & 10 \\
\hline \multicolumn{6}{|l|}{ Nematoda } \\
\hline Diplotriaena bargusinica Skrjabin, 1917 & $\mathrm{Mb}^{*} 2, \mathrm{Mb}^{*} 4, \mathrm{Mb}^{*} 5$ & $18 ; 18 ; 1$ & 60 & 7.4 & 12.3 \\
\hline Synhimantus $(D$.$) nasuta Skrjabin, 1917$ Chabaud, 1975 & $\mathrm{Mb}^{*} 5$ & 2 & 20 & 0.4 & 2 \\
\hline
\end{tabular}



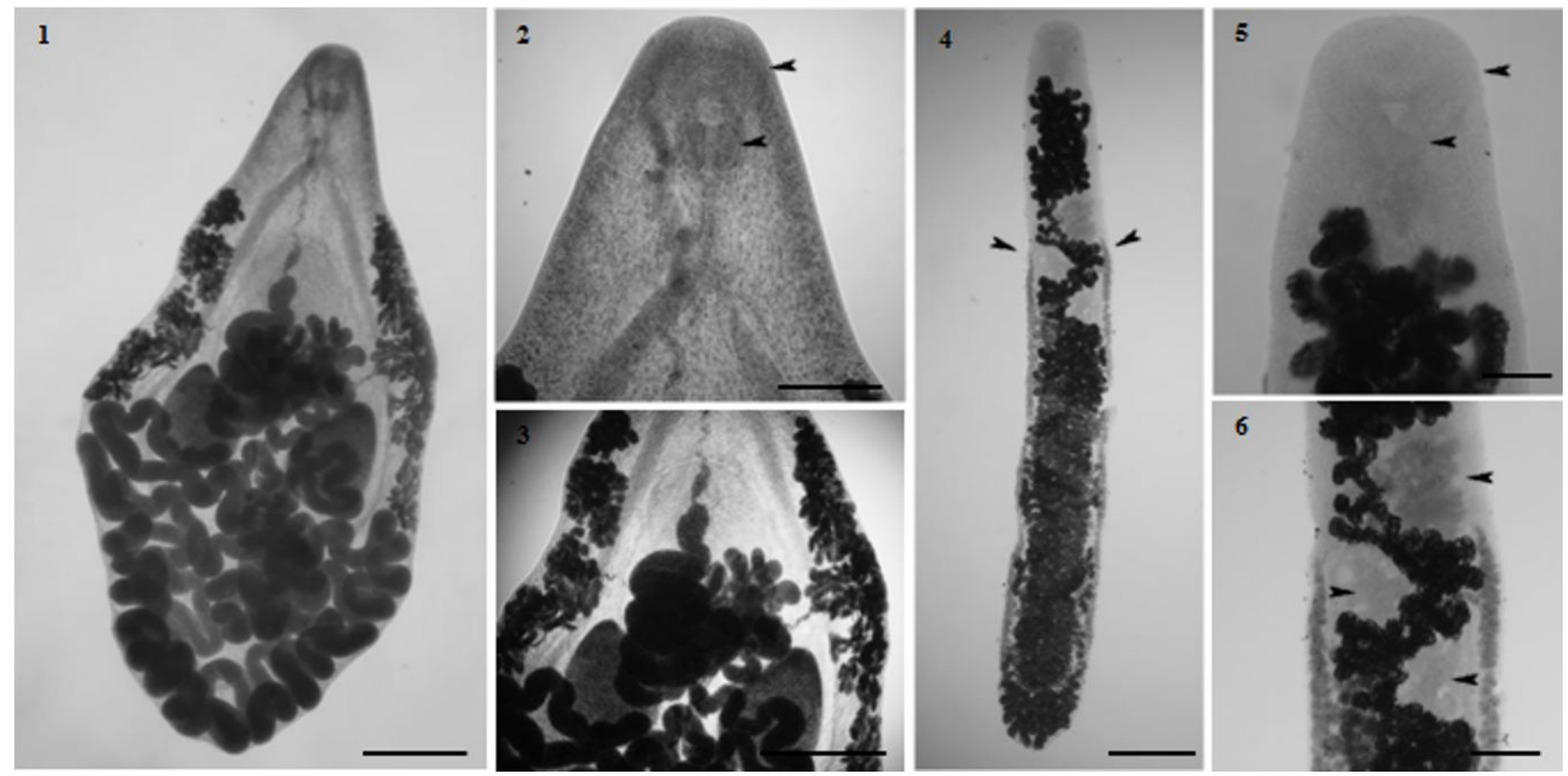

Figure 1-6. 1-3- Prosthogonimus ovatus (Rudolphi, 1803) (Lühe, 1899) (Trematoda: Prostogonimidae) of Molothrus bonariensis (Gmelin, 1789) (Passeriformes: Icteridae) from southern Brazil. 1- ventral view of $P$. ovatus; bar $=0.6 \mathrm{~mm}$; 2- arrows point to the oral suckers and pharynx; bar $=0.25 \mathrm{~mm}$; 3- median area of the body, vitellarias, ovary and testicles; bar $=0.68 \mathrm{~mm}$. 4-6 Tanaisia valida Freitas, 1951 (Trematoda: Eucotylidae) of $M$. bonariensis. 4- ventral view of T. valida; Arrows point out the beginning of the vitelline glands; bar = $0.39 \mathrm{~mm} ; 5$ - anterior area, arrows point to the terminal oral sucker and pharynx; bar $=0.08 \mathrm{~mm}$; 6 - median area of the body, arrows point to ovary and lobate testes; bar $=0.14 \mathrm{~mm}$.

cloaca or nictitating membrane of birds, in mammals are found in the intestine, liver and body cavity (BRAY et al., 2008).

In Brazil, P. ovatus were registered in the bursa of Fabricius of Gallus gallus domesticus (Linnaeus, 1758) (Galliformes: Phasianidae) $(\mathrm{n}=17) \mathrm{P}=17.6 \%$ and in wild birds: Theristicus caerulescens (Vieillot, 1817) $(\mathrm{n}=6) \mathrm{P}=16.6 \%$; Mesembrinibis cayennensis (Gmelin, 1789) ( $=3$ ) $\mathrm{P}=33.3 \%$ (Pelecaniformes: Threskiornithidae); Piaya cayana (Linnaeus, 1766) (Cuculiformes: Cuculidae) $(\mathrm{n}=3) \mathrm{P}=33.3 \%$; Monasa nigrifrons (Spix, 1824) (Galbuliformes: Bucconidae) ( $\mathrm{n}=10) \mathrm{P}=10.0 \%$ Cyanocorax cyanomelas (Vieillot, 1818) (Passeriformes: Corvidae) $(\mathrm{n}=4) \mathrm{P}=25.0 \%$ Xiphorhynchus guttatus (Lichtenstein, 1820) (Passeriformes: Dendrocolaptidae) ( $\mathrm{n}=1) \mathrm{P}=100 \%$ (TRAVASSOS, 1928; TRAVASSOS et al., 1969).

Kohn \& Fernandes (1972) reported the ocurrence of P. ovatus in Pteroglossus aracari (Linnaeus, 1758) (Piciformes: Ramphastidae), Cairina moschata (Linnaeus, 1758) and Cairina moschata domesticus (Anseriformes: Anatidae), Crotophaga major Gmelin, 1788 (Cuculiformes: Cuculidae), Theresticus caerulescens (Vieillot, 1817) (Pelecaniformes: Threskiornithidae), Hydropsalis Wagler, 1832 (Caprimulgiformes: Caprimulgidae), Leptoptila verreauxi Bonaparte, 1855 (Columbiformes: Columbidae), in the Charadriiformes: Thalasseus maximus (Boddaert, 1783) (Sternidae), Gallinago paraguaiae (Vieillot, 1816) (Scolopacidae), Larus Linnaeus, 1758 and Larus dominicanus (Laridae) in Passeriformes: Tangara sayaca (Linnaeus, 1766) and Lanio melanops (Vieillot, 1818) (Thraupidae), Turdus amaurochalinus Cabanis, 1850 (Turdidae), Taraba major Gmelin, 1788 (Thamnophilidae), Cyanocorax chrysops
(Vieillot, 1818) (Corvidae), Icterus croconotus (Wagler, 1829) and Sturnella superciliaris (Bonaparte, 1840) (Icteridae).

In Rio Grande do Sul, Monteiro et al. (2007) identified P. ovatus in waterbirds, Dendrocygna bicolor (Vieillot, 1816) ( $\mathrm{n}=33), \mathrm{P}=3.0 \%$ and $\mathrm{MI}=1$; and Netta peposaca (Vieillot, 1816) ( $\mathrm{n}=20), \mathrm{P}=15.0 \%$ and $\mathrm{MI}=4.3$ (Anseriformes: Anatidae); and in Phalacrocorax brasilianus (Gmelin, 1789) ( $\mathrm{n}=47$ ), $\mathrm{P}=2.1 \%$ and MI = 1 (Suliformes: Phalacrocoracidae). Mascarenhas et al. (2009) identified it in Paroaria coronata (Miller, 1776) $(\mathrm{n}=40)$, $\mathrm{P}=7.5 \%$ and $\mathrm{MI}=3$ (Passeriformes: Thraupidae).

According to Boddeke (1960) the life cycle of P. ovatus involves two intermediate hosts, the first is a mollusk and the second are young forms of Odonata. The bird infection occurs through ingestion of young or adult dragonflies containing the encysted metacercariae (BODDEKE, 1960). In laying birds, they affect egg production, through causing a decline in egg formation, or non-formation (OLSEN, 1974).

Tanaisia Skrjabin, 1924, parasitizes the renal tubules and kidneys of birds. In Brazil, it has mainly been reported in Passeriformes, although there have been records of occurrences in Cuculiformes, Charadriiformes, Gruiformes and Strigiformes. The Eucotylidae taxonomy is a complex one due to morphological structures that characterize the genera and species (integument, position and shape of the testis and ovaries, etc.).

Lunaschi et al. (2015) redescribed Tanaisia dubia Freitas, in 1951, had created a key to the Neotropical species Tanaisia and a key to the Tanaisiinae genres that gives support in species 

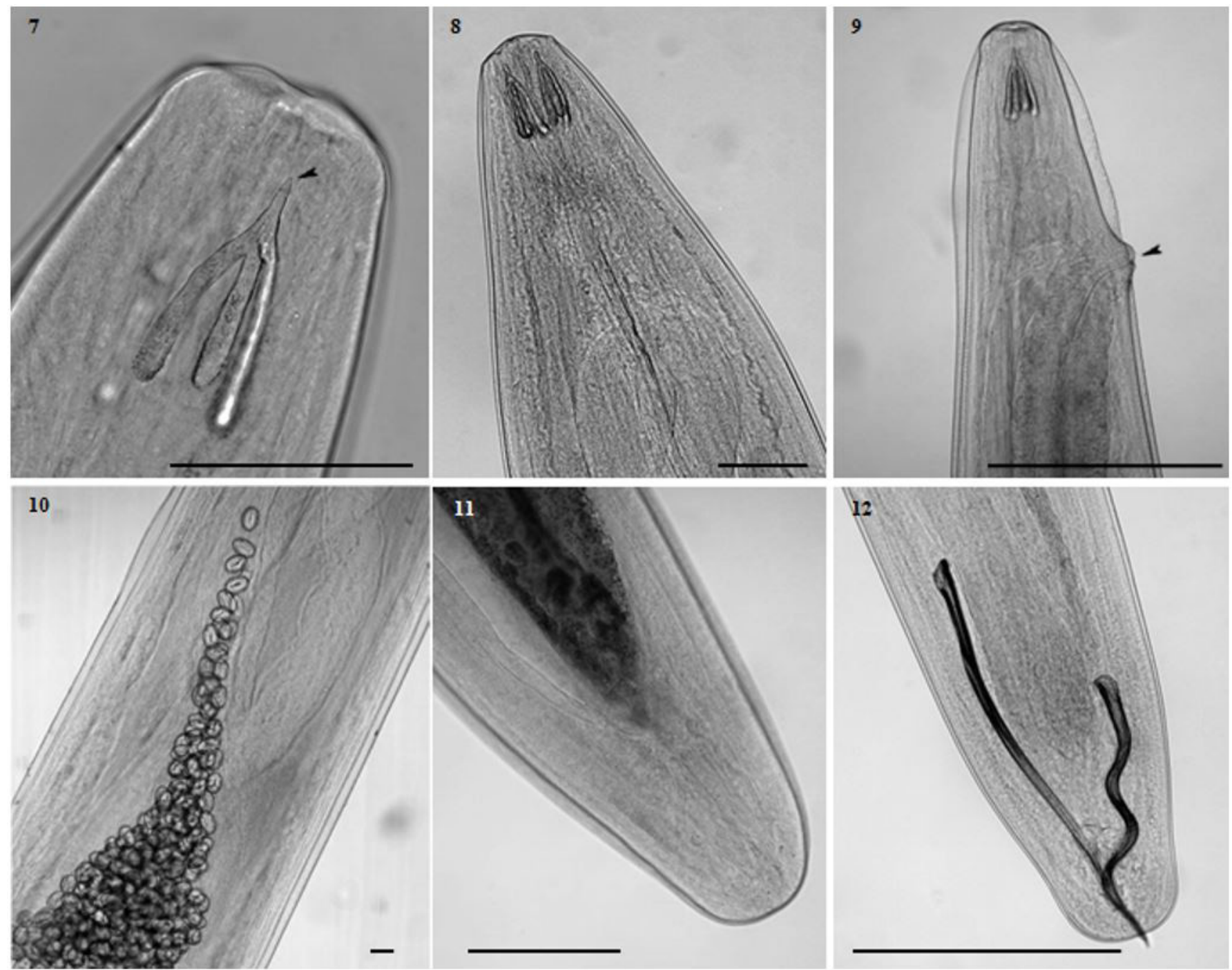

Figure 7-12. Diplotriaena bargusinica Skrjabin, 1917 (Nematoda: Diplotriaenidae) of Molothrus bonariensis (Gmelin, 1789) (Passeriformes: Icteridae) from southern Brazil. 7- dorsal view, smooth trident highlighted, arrow points to the apex of the tapered trident. bar $=0.14 \mathrm{~mm}$; 8 - dorsal view of the anterior area; bar $=0.14 \mathrm{~mm}$; 9 - anterior area of the female, arrow points to genital opening; bar $=0.35 \mathrm{~mm} ; 10$ - posterior area of the male, detail of bigger and smaller spicules; bar $=0.5 \mathrm{~mm}$; 11 - posterior area of the female; bar $=0.25 \mathrm{~mm}$; 12 - median area of the female, detail of the eggs; bar $=0.05 \mathrm{~mm}$.

identification. Those authors pointed out the extent of vitelline glands as an important morphological characteristic to distinguish three genres of Tanaisiinae, and in the species of Tanaisia the vitelline glands extend up from ovarian or testicular region.

Tanaisia valida Freitas, 1951 was described in Himantopus melanurus Vieillot, 1817 (Charadriiformes: Recurvirostridae) in the state of Rio de Janeiro and, later on, was reported by Mascarenhas et al. (2009), in Paroaria coronata (Miller, 1776) (Passeriformes: Thraupidae) $(\mathrm{n}=40)$, with $\mathrm{P}=2.5 \%, \mathrm{MA}=0.05$ and $\mathrm{MI}=2$, in the state of Rio Grande do Sul.

In South America, other authors have had identified T. valida in Charadriiformes. In Peru, Ibañez-Herrera (1998) recorded T. valida parasitizing kidneys in Himantopus melanurus Vieillot, 1817 (Recurvirostridae) without presenting parasitological and sample size indexes, because it is a list of species for the fauna of Peru, later Tantalean et al. (1992) recorded in Phalaropus tricolor
(Vieillot, 1819) (Scolopacidae) in the same country. Tanaisia valida was identified in Charadrius wilsonia Ord, 1814 (Charadriidae) $(\mathrm{n}=1)(\mathrm{P}=100 \%)(\mathrm{MI}=4)$ in Colombia (LUNASCHI et al. 2015).

About the life cycle of T. valida does not exist information, however considering the life cycle of Tanaisiinae, the birds become infected by ingesting (Mollusca: Gastropoda) containing metacercariae (LUNASCHI et al. 2015).

Diplotriaena Railliet \& Henry, 1909, has parasitic specificity restricted to birds and is distributed among Anseriformes, Apodiformes, Galliformes, Charadriiformes, Columbiformes, Piciformes and Passeriformes, with wide geographic distribution (VICENTE et al., 1983; ATKINSON et al., 2009).

In Brazil D. bargusinica was reported by Vicente et al. (1983) parasitizing some Passeriformes in different areas of the country: Cacicus cela (Linnaeus, 1758), Cacicus haemorrhous (Linnaeus, 1766), 

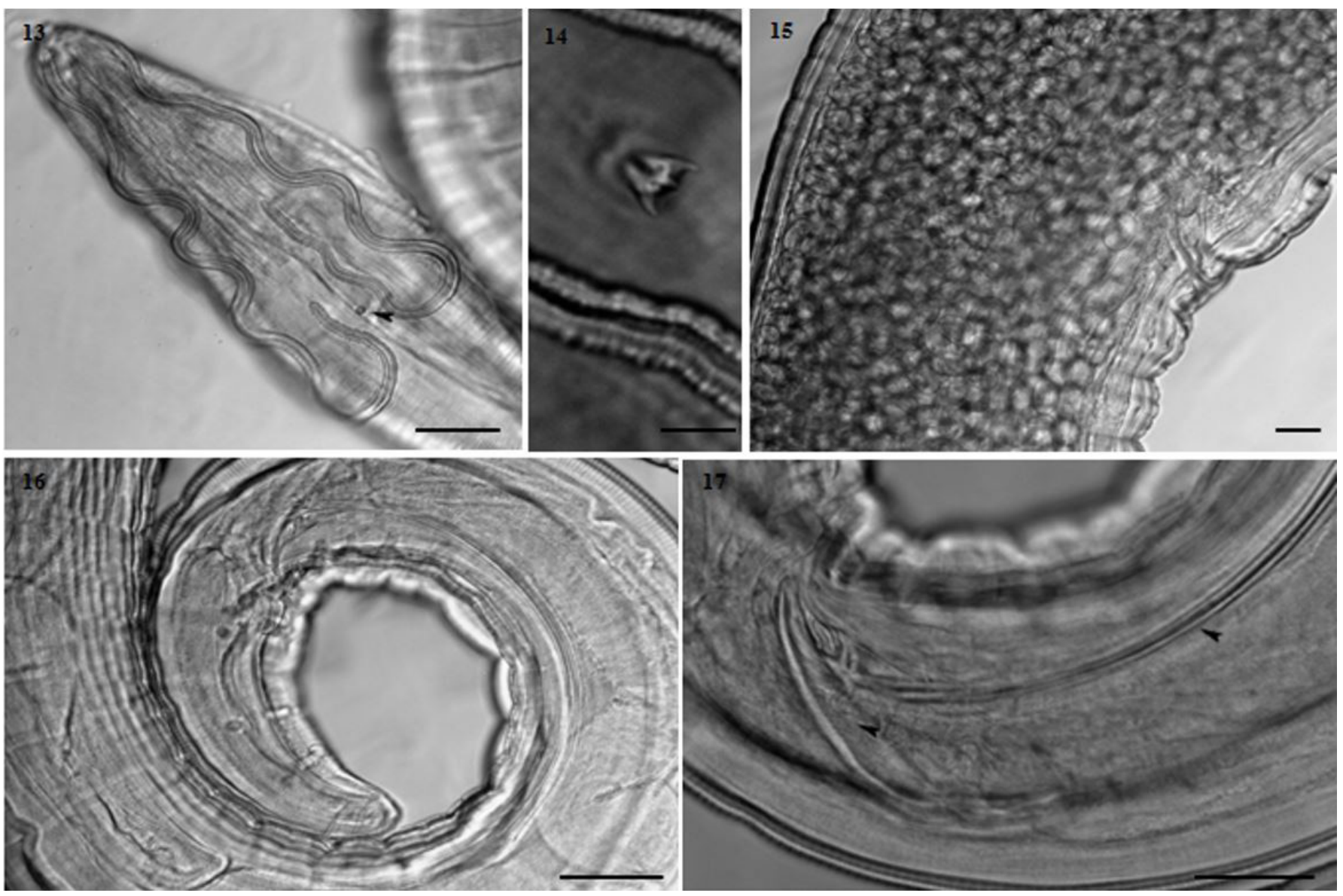

Figure 13-17. Synhimantus (Dispharynx) nasuta (Rudolphi, 1819) Chabaud, 1975 (Nematoda: Acuariidae) of Molothrus bonariensis (Gmelin, 1789) (Passeriformes: Icteridae) from southern Brazil. 13- recurrent cordons of $S$. (D.) nasuta, arrow points to the papilla; bar = $0.07 \mathrm{~mm} ; 14$ - detain of the bifurcated cervical papilla; bar $=0.01 \mathrm{~mm} ; 15$ - genital opening of the female; bar $=0.03 \mathrm{~mm}$; 16 - posterior area of the male, detail of pre and post-cloacal papillae; bar $=0.17 \mathrm{~mm} ; 17$ - lateral view, arrows point to uneven spicules; $\mathrm{BAR}=0.8 \mathrm{~mm}$.

Gnorimopsar chopi (Vieillot, 1819), Icterus croconotus (Wagler, 1829), Icterus sp., Psarocolius decumanus maculosus (Chapman, 1920), Molothrus bonariensis (Gmelin, 1789) (Icteridae) and Xiphocolaptes major castaneus Ridgway, 1890 (Dendrocolaptidae), in the states of Mato Grosso do Sul, São Paulo and Pará and in Paraguay, without informing the number of birds examined or their indexes.

Pinto et al. (1997) reported the presence of D. bargusinica for the first time in Cyanocorax cyanomelas (Vieillot, 1818) (Corvidae) in the state of Mato Grosso do Sul, from samples collected between 1921 and 1925 in scientific expeditions conducted in Brazil, without informing the number of birds examined or their indexes. Gonçalves et al. (2002) found D. bargusinica in the body cavity of three individuals of Psarocolius bifasciatus (Spix, 1824) (Icteridae) in the state of Amazonas and Carvalho et al. (2007) in air sacs of Paroaria dominicana (Linnaeus, 1758) (Emberizidae) $(\mathrm{n}=34)$, $\mathrm{P}=8.8 \%, \mathrm{MA}=0.32$ and $\mathrm{MI}=3.66$, in the state of Bahia.

Anderson (1962), performed experimental infection with $D$. bargusinica in wild birds (Turdidae and Icteridae) and described details of its biological cycle which uses grasshoppers (Orthoptera) as intermediate hosts. Birds become infected by ingesting grasshoppers that contain third-stage larvae, and the adult nematodes become established in the air sacs of the host (ANDERSON, 2000). The clinical signs common to parasitized birds are lethargy, labored breathing, size and weight below average and little plumage (ATKINSON et al., 2009).

Synhimantus (D.) nasuta has worldwide distribution and parasitizes the proventriculus and gizzard of birds. In Brazil, it has been found in Galliformes of economic importance, and also in Columbiformes, Cuculiformes, Strigiformes, Falconiformes, Charadriiformes and Passeriformes (BARTMANN \& AMATO, 2009).

In Rio Grande do Sul, S. (D.) nasuta was reported in Paroaria coronata (Miller, 1776) (Passeriformes: Thraupidae) $(\mathrm{n}=40), \mathrm{P}=2.5 \%, \mathrm{MA}=0.1$ and $\mathrm{MI}=4$, by Mascarenhas et al., 2009; in Guira guira (Gmelin, 1788) ( $\mathrm{n}=120$ ), $\mathrm{P}=28.3 \%$, $\mathrm{MA}=2.28$ and $\mathrm{MI}=8.8$; in Crotophaga ani Linnaeus, 1758 (Cuculiformes: Cuculidae) $(\mathrm{n}=120), \mathrm{P}=26.7 \%, \mathrm{MA}=1.32$ and $\mathrm{MI}=5.1$, by Bartmann \& Amato (2009); in Columbina picui (Columbiformes: Columbidae) $(\mathrm{n}=34), \mathrm{P}=5.9 \%, \mathrm{MA}=$ 1.1 and MI = 19.5, by Coimbra et al. (2009); in Vanellus chilensis (Molina, 1782) (Charadriiformes: Charadriidae) $(\mathrm{n}=28), \mathrm{P}=$ 28.6\%, MA = 4.11 and $\mathrm{MI}=14.38$, by Avancini (2009); in Passer domesticus (Linnaeus, 1758) (Passeriformes: Passeridae) $(\mathrm{n}=$ 
160), $\mathrm{P}=0.63 \%, \mathrm{MA}=0.11$ and $\mathrm{MI}=18$, by Calegaro-Marques \& Amato (2010); and in Pitangus sulphuratus (Passeriformes: Tyrannidae) $(\mathrm{n}=78), \mathrm{P}=3.85 \%, \mathrm{MA}=0.10$ and $\mathrm{MI}=2.66$, by Mendes (2011).

The biological cycle of $S$. (D.) nasuta is heteroxenous, using terrestrial isopods, orthopterans, beetles or millipedes (GOBLE \& KUTZ, 1945). The larvae develop in non-specific tissues of isopods, in which they become encapsulated and are later on ingested by birds (ANDERSON, 2000). The effects on the definitive host are related to the parasitic load, usually comprising inflammations, granulomas and lesions in the proventriculus. In wild birds, these macroscopic and histopathological alterations were described by Bartmann \& Amato (2009).

In general, the parasitological indexes of $M$. bonariensis are similar to those found by those previously mentioned authors, considering that the previous studies had sample sizes close to the one of the present study future research is needed to complement existing information in order to contribute to the understanding of the biology and ecology of these organisms.

In Brazil, for the first time the species T. valida, P. ovatus e $S$. (D.) nasuta are recorded parasitizing $M$. bonariensis. Prosthogonimus ovatus, $T$. valida, D. bargusinica e $S$. (D.) nasuta characterize first record in $M$. bonariensis in Rio Grande do Sul. Whereas the helminthological information for the specie are scarce, this work expands the knowledge to Icteridae and Molothrus bonariensis.

\section{Acknowledgements}

The authors thank the contributions of the reviewers of the Brazilian Journal of Veterinary Parasitology, at the Coordenação de Aperfeiçoamento do Pessoal de Nível Superior (CAPES) for the doctoral scholarship of the first author, for the financial support provided through announcement no. 2010/032 and Granjas 4 Irmãos S.A. for its assistance in collecting the birds on its property.

\section{References}

Amato JFR, Amato SB. Técnicas gerais para coleta e preparação de helmintos endoparasitos de aves. In: Von Matter S, Straube FC, Accordi I, Piacentini V, Cândido JF Jr. Ornitologia e conservação: ciência aplicada, técnicas de pesquisa e levantamento. Rio de Janeiro: Technical Books; 2010. p. 369-393.

Anderson RC, Chabaud AG, Willmott S. Keys to the Nematode parasites of vertebrates: archival volume. London: CABI International; 2009. 463 p.

Anderson RC. Nematode parasites of vertebrates: their development and transmission. 2nd ed. London: CABI International; 2000. 650 p.

Anderson RC. On the development, morphology, and experimental transmission of Diplotriaena bargusinica (Filaroidea: Diplotriaenidae). Can JZool 1962; 40(7): 1175-1186. http://dx.doi.org/10.1139/z62-093.

Astié AA, Reboreda JC. Costs of egg punctures and parasitism by shiny cowbirds (Molothrus bonariensis) at creamy-bellied thrush (Turdus amaurochalinus) nests. Auk 2006; 123(1): 23-32. http://dx.doi. org/10.1642/0004-8038(2006)123[0023:COEPAP]2.0.CO;2.

Atkinson CT, Thomas NJ, Hunter DB. Parasitic diseases of wild birds. Ames: Wiley-Blackwell; 2009. 592 p.
Avancini LF. Helmintos e artrópodes de Vanellus chilensis (Molina, 1782) quero-quero, da regiāo sul do Rio Grande do Sul [Dissertação]. Pelotas: Universidade Federal de Pelotas; 2009.

Bartmann A, Amato SB. Dispharynx nasuta (Nematoda: Acuariidae) em Guira guira e Crotophaga ani (Cuculiformes: Cuculidae) no Estado do Rio Grande do Sul, Brasil. Cienc Rural 2009; 39(4): 1152-1158. http:// dx.doi.org/10.1590/S0103-84782009005000059.

Belton W. Aves do Rio Grande do Sul: distribuição e biologia. São Leopoldo: UNISINOS; 1994.548 p.

Blanco DE. Parasitismo de cria del Tordo Renegrido Molothrus bonariensis sobre Agelaius ruficapillus, en el este de la província de Buenos Aires. El Hornero 1995; 14(1-2): 44-45.

Boddeke R. The life history of Prosthogonimus ovatus Rudolphi II. The intermediate hosts. Trop Geogr Med 1960; 12: 363-377.

Bray RA, Gibson DI, Jones A. Keys to Trematoda. London: CABI International/Natural History Museum; 2008. vol. 3, 824 p.

Bush AO, Lafferty KD, Lotz JM, Shostak AW. Parasitology meets ecology on its own terms: Margolis et al. revisited. J Parasitol 1997; 83(4): $575-$ 583. http://dx.doi.org/10.2307/3284227. PMid:9267395.

Calegaro-Marques C, Amato SB. Helminths of introduced house sparrows (Passer domesticus) in Brazil: does population age affect parasite richness? Iheringia. Série Zool 2010; 100(1): 73-78.

Carvalho AR, Daemon E, Souza-Lima S. Relação entre o peso do baço e infecção por helmintos em galo de campina Paroaria dominicana (Linnaeus, 1758) (Passeriformes, Emberizidae) do estado da Bahia, Brasil. Rev Bras Zooc 2007; 9(2): 219-224.

Coimbra MAA, Mascarenhas CS, Krüger C, Muller G. Helminths parasitizing Columbina picui (Columbiformes: Columbidae) in Brazil. J Parasitol 2009; 95(4): 1011-1012. http://dx.doi.org/10.1645/GE1948.1. PMid:20050007.

Efe MA, Mohr LV, Bugoni L. Guia ilustrado das aves dos parques de Porto Alegre. Porto Alegre: PROAVES/SMAM/COPESUL/CEMAVE; 2001. 144 p.

Freitas JFT. Revisão da família Eucotylidae Skrjabin, 1924 (Trematoda). Mem Inst Oswaldo Cruz 1951; 49: 33-123. http://dx.doi.org/10.1590/ S0074-02761951000100003. PMid:14890534.

Gibson DI, Jones A, Bray RA. Keys to the Trematoda. London: CABI International/The Natural History Museum; 2002. vol. 1, 521 p.

Goble FC, Kutz HL. The genus Dispharynx (Nematoda: Acuariidae) in Galliform and Passariform birds. J Parasitol 1945; 31(5): 323-331. http:// dx.doi.org/10.2307/3273088.

Goméz A, Nichols E. Neglected wild life: Parasitic biodiversity as a conservation target. Int J Parasito. Parasit Wildl 2013; 2: 222-227. http:// dx.doi.org/10.1016/j.ijppaw.2013.07.002.

Gonçalves AQ, Vicente JJ, Pinto RM. Nematodes of Amazonian vertebrates deposited in the Helminthological Collection of the Oswaldo Cruz Institute with new records. Rev Bras Zool 2002; 19(2): 453-465. http:// dx.doi.org/10.1590/S0101-81752002000200011.

Hoberg EP, Kutz SJ. Parasites. In: Bültmann H, Ims RA, Fridriksson F, Hoberg EP, Meltofte H, Ganter B, Josefson A. Artic biodiversity assessment: status and trends in Artic biodiversity [online]. Akureyri: Conservation of Arctic Flora and Fauna; 2013 [cited 2015 Sep 02] . Available from: http:// www.arcticbiodiversity.is/the-report/chapters/parasites 
Ibañez-Herrera, N. Mención de algunos tremátodos en la fauna helmintológica peruana. Rev Per Parasit 1998; 13: 90-96.

Kohn A, Fernandes BMM. Sobre a valiedade das espécies pertencentes ao gênero Prosthogonimus Luehe, 1899, da coleçáo helmintológica do Instituto Oswaldo Cruz. Mem Inst Oswaldo Cruz 1972; 70(3): 309-325. http://dx.doi.org/10.1590/S0074-02761972000300005.

Lunaschi LI, Drago FB, Draghi R. Redescription of Tanaisia dubia (Digenea) from the northeast region of Argentina, with a key to Neotropical species of the genus, and a key to genera of Tanaisiinae. Rev Mex Biodiv 2015; 86(4): 888-895. http://dx.doi.org/10.1016/j.rmb.2015.06.012.

Mascarenhas CS, Krüger C, Müller G. The helminth fauna of the redcrested cardinal (Paroaria coronata) Passeriformes: Emberizidae in Brazil. Parasitol Res 2009; 105(5): 1359-1363. http://dx.doi.org/10.1007/ s00436-009-1569-8. PMid:19636590.

Mendes MM. Helmintos e ácaros nasais parasitos de Pitangus sulphuratus (Passeriformes: Tyrannidae), bem-te-vi, no Rio Grande do Sul [Dissertação]. Pelotas: Universidade Federal de Pelotas; 2011.

Mermoz ME, Reboreda JC. Reproductive sucess of shiny cowbird (Molothrus bonariensis) parasitizing the larger brown-and-yellow marshbird (Pseudoleistes virescens) in Argentina. Auk 2003; 120(4): 1128-1139. http:// dx.doi.org/10.1642/0004-8038(2003)120[1128:RSOSCM]2.0.CO;2.

Monteiro CM, Amato JFR, Amato SB. Prosthogonimus ovatus (Rudolphi) (Digenea, Prosthogonimidae) em três espécies de aves aquáticas da Regiāo Sul do Brasil. Rev Bras Zool 2007; 24(1): 253-257. http://dx.doi. org/10.1590/S0101-81752007000100035.

Olsen OW. Animal parasites: their life cycles and ecology. Baltimore: University Park Press; 1974. 562 p.

Petrochenko VI. Acanthocephala of domestic and wild animals. Jerusalém: Israel Program for Scientific Translations; 1971. vol. 2, 478 p.
Pinto RM, Vicente JJ, Noronha D. Nematode Parasites of Brazilian Corvid Birds (Passeriformes): a general survey with a description of Viktorocara brasiliensis n. sp. (Acuariidae, Schistorophinae). Mem Inst Oswaldo Cruz 1997; 92(2): 209-214. http://dx.doi.org/10.1590/S007402761997000200013.

Poulin R, Morand S. The diversity of parasites. Q Rev Biol 2000; 75(3): 277-293. http://dx.doi.org/10.1086/393500. PMid:11008700.

Sick H. Ornitologia brasileira. Rio de Janeiro: Editora Nova Fronteira; 1997. 862 p.

Tantalean M, Sarmiento LB, Huiza AF. Digeneos (Trematoda) del Perú. Bol Lima 1992; 80: 47-84.

The IUCN Red List of Threatened Species [online]. Gland: International Union for Conservation of Nature and Natural Resources; 2015 [cited 2015 Aug 20]. Available from: http://www.iucnredlist.org.

Travassos L, Teixeira de Feitas JF, Kohn A. Trematódeos do Brasil. Mem Inst Oswaldo Cruz 1969; 67: 1-886.

Travassos L. Fauna helminthologica de Matto Grosso (Trematódeos - $1^{\text {a }}$ parte). Mem Inst Oswaldo Cruz 1928; 21(2): 323-338. http://dx.doi. org/10.1590/S0074-02761928000200002.

Vicente JJ, Pinto RM, Noronha D. Estudo das espécies brasileiras do gênero Diplotriaena Henry \& Ozoux, 1909 (Nematoda, Filarioidea). Mem Inst Oswaldo Cruz 1983; 78(2): 165-182. http://dx.doi.org/10.1590/ S0074-02761983000200005.

Zhang L, Brooks DR, Causey D. Two species of Synhimantus (Dispharynx) Railliet, Henry and Sisoff, 1912 (Nematoda: Acuarioidea: Acuariidae) in passerine birds from the area the Conservación Guanacaste, Costa Rica. J Parasitol 2004; 90(5): 1133-1138. http://dx.doi.org/10.1645/ GE-3253. PMid:15562615. 